\title{
The Role of Archaeology in Forming Greek National Identity and its Embodiment in European Identity
}

\author{
OLGA KATSIAR D I - HER ING \\ National and Kapodistrian University of Athens, Athens, Greece. \\ Email: olkats@arch.uoa.gr
}

The murder of Johann Joachim Winckelmann, for many the 'founder of archaeology', in 1768 in a Trieste inn, did not mean the end for his work, which could be said to have been the key to understanding ancient Greece, which Europe was re-discovering at the time. In the late Enlightenment, Neoclassicism, followed by Romanticism, elevated classical, Hellenistic and Roman antiquity, and archaeological research, to the centre of academic quests, while the inclusion of archaeological sites in the era's Grand Tours fed into a belief in the 'Regeneration'/ 'Wiedergeburt' of Greece. The Modern Greek Enlightenment flourished during this same period, the late eighteenth and early nineteenth centuries, with a concomitant classicizing turn. Ancient Greek texts were republished by Greek scholars, especially in the European centres of the Greek diaspora. An admiration for antiquity was intertwined into the Neohellenic national identity, and the first rulers of the free Greek State undertook to take care of the nation's archaeological monuments. In 1837, under 'Bavarian rule', the first Greek University and the 'Archaeological Society of Greece in Athens' were set up. Archaeologists flocked to Greece and those parts of the ancient Greek world that were still part of the Ottoman Empire. The showcasing of classical monuments, at the expense of the Byzantine past, would remain the rule until the latter half of the nineteenth century. Modern Greek national identity was primarily underpinned by admiration for antiquity, which was viewed as a source of modern Hellenism, and for 'enlightened, savant, good-governed Europe'. Today, the 'new archaeology' is striving to call these foundations into question.

In this article, I thought I could combine my studies in archaeology - and my love of it - with my research on the Modern Greek Enlightenment era (end of the eighteenth century and beginning of the nineteenth century) and on the formation of the first 
Nation-State in Southeastern Europe in the aftermath of the Greek Revolution (1821). The subject was already a widely discussed one in the nineteenth century, as a consequence of classicism and romanticism. Its recent revival in a debate among archaeologists and historians can be explained because of the rethinking of nationalism, of postmodern trends and of constructivist ideas both within the framework of postcolonial studies and beyond (Díaz-Andreu and Champion 1996; Damaskos and Plantzos 2008; Voutsaki and Cartledge 2017). The stereotypes (Focus 2010, 2011; Dettmer et al. 2013) peddled by European mass and social media as well as politicians during the recent and critical Greek economic crisis attest to deep-rooted perceptions about the relationship between the ancient Hellenic past and the establishment of the Modern Greek State. Perceptions about the continuity and discontinuity of Greek and other European histories and civilizations, and also of belonging or not to the European family emerged in a new and, unfortunately, polemic perspective. The role of Archaeology as a handmaiden in the re-emergence of recent nationalisms, particularly in Southeastern Europe, is still worrying, as is the fact that its testimonial evidence is often not used in a scientific way.

I shall begin my article in a slightly 'unorthodox' fashion. In the year 1976, I travelled to Trieste to conduct research in its archives and libraries for my doctoral dissertation about the presence of the flourishing Greek commercial community/ colony in this erstwhile free Habsburg port (Katsiardi-Hering 2018). Some days after my arrival, I visited one of the central local museums and I stood in front of the cenotaph (Museo d'Antichità 2015) of the great German archaeologist Johann Joachim Winckelmann. In June 1768, on his way to the Greek lands, then under Ottoman rule, Winckelmann spent a night at the Locanda Grande (Quitrieste 2012) in the centre of the town, where he was, unfortunately, murdered. The details of the event are somewhat murky. But what is crystal-clear, however, is his thorough work on the ancient Greek monuments had an enormous influence on the then nascent university discipline of Archaeology (Leppmann 1986). In one of his writings he said: 'There is but one way for the moderns to become great, even inimitable; I mean, by imitating the Greeks' (Fatsea 2017). Some 30 years later, in the year 1797 and in the same Locanda grande, the Greek visionary revolutionist Rigas Velestinlis was arrested after having been betrayed by a Greek merchant in Trieste to the local Habsburg police (Katsiardi-Hering 1999, 59-81). In the Greek printing house in Vienna - where two important Greek commercial communities flourished (Seirinidou 2010) - this great intellectual of the Enlightenment era had secretly published many books, including a Constitution of the 'Hellenic Republic' (imitating the French Constitution of 1793), Man's Rights, the Greek Marseillaise (Thourios), etc. He had sent these texts clandestinely to Trieste with a view to distributing them in the Greek lands after landing on the Ionian Islands, where Bonaparte - with whom he was probably in secret communication - that same year, 1797 and after the fall of Venice, had landed in Corfu as liberator and conqueror. Rigas' goal was to provoke a revolution for the liberation of all Balkan peoples, but particularly the Greeks. Among the rest of his publications were: an Engraving of Alexander the Great,

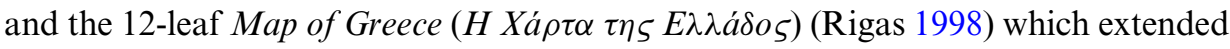


as far as the Danube, in accordance with his vision of the 'Hellenic Republic' and its constitution, which referred to all Southeastern European peoples and not only to the Greeks (Kitromilides 2013). For the most part, the Map uses the ancient Greek place names. The margins of the map feature Greek and Hellenistic coins, as well as archaeological details relating to celebrated ancient Greek historical sites. Rigas also published a Greek translation of Jean-Jacques Barthélémy's Le Voyage du jeune Anacharsis en Grèce, dans le milieu du quatrième siècle avant l'ère vulgaire (Tolias 2005, 67-91). This can be seen as the 'manifesto of the movement [at the end of the eighteenth century] which proclaimed a regeneration of the Greek antiquity' (Tolias 2012, 86). After a long interrogation by the Habsburg authorities, Rigas was delivered to the Ottomans in Belgrade. The following year (1798) he was assassinated in the Neboisa castle on the Danube (Nebojsa Tower 2014). National and revolutionary activities were neither allowed nor even tolerated in multi-ethnic empires.

The death of Rigas did not rein in Greek revolutionary plans and visions of liberation from the Ottomans and the founding of a Greek nation state (Katsiardi-Hering 1989, 87-118; 2009, 96-137). Similarly, the death of Winckelmann did not stem European interest in ancient Greek and Roman antiquities. In the context of the Grand Tour, but also in the framework of the growing classicist trend in Europe (Kouria 2016), many travellers or representatives of western European authorities and academies travelled to the lands inhabited by Greeks and other Southeastern European peoples, who were still under the rule of the Ottoman Empire, Venice or England. These trips were motivated by academic and other reasons, but also by 'marble fever'. Since the Renaissance, Greece was considered 'as the cradle of Philosophy, of the Arts' (Tolias 2012, 87), and of the political thought of Europe. Behind this 'fever of marbles' one can truly discern the crypto-colonial behaviour (Tolias 2011, 88) of Western Europeans, particularly at the end of the eighteenth century and the beginning of the nineteenth century. Some of these travellers even had, as a mission, to bring back as many fragments of the antiquities as they could find, for the enrichment of the newly established, national museums in the capital cities of Europe, worthy successors of the private collections of the Renaissance and postRenaissance (Chatzidimitriou 2012, 33-78). One should view the transport of Greek antiquities by ambassadors and consuls in the Ottoman Empire, such as ChoiseulGouffier or Fauvel (Eldem 2011, 287-288), to the Louvre and elsewhere in this light (Halbertsma 2003). The best-known example, of course, is the removal of the so-called 'Elgin marbles', now in the British Museum, from the Parthenon (Matthaiou and Chatzidimitriou 2012). This has often been considered sheer 'plunder' (Tolias 2008, 55-56). Alternatively, it has also been seen as an effort to protect them from the neglect of the Ottomans and the locals: a genuine orientalist argument! The fevered debate of the past decades (King 2006; Wikipedia 2017) over the possible restitution of these marbles to the new Acropolis Museum in Athens has shed light on the strong connection between Archaeology and History and the role both play in the formation of national or supra-national European identities. Issues that have featured in the heated discussion include the question of to whom these artefacts 'belong': the land 
where they were produced centuries ago, the modern Greek nation state, or humanity at large?

At this point, we have to think about the time when perceptions or concepts such as 'cultural or natural heritage', or even 'protection of the natural/economic/cultural environment' were totally unknown (Smith 2004; Papadia-Lala 2015, 361-370; Matthaiou 2012, 15-32; Voudouri 2015, 293-306). The imperial (Ottoman or even Venetian) authorities took a very different approach to the antiquities in the lands under their jurisdiction. These antiquities often belonged to civilizations towards which some of these authorities maintained a 'blissful indifference' (Eldem 2011). The unfortunate bombardment of the Acropolis by the Venetians during the Ottoman-Venetian war of 1685-1687 is a well-known example (Stouraiti 2001; Chatsiaslani 2016). It is interesting to compare this attitude with the strict warnings by the British Ambassador, Sir Stratford Canning, to the Ottoman authorities during the siege of the Acropolis in 1826: the Ottoman commander-in-chief, Mehmed Reşid Pasha, was to avoid destroying the Parthenon and its surrounding antiquities 'as they have been made with the greatest skill and art in the science of building and construction, they have truly become examples to the entire world' (Eldem 2011, 297-301). After this the Ottomans slowly began to change their stance towards the Classical, Hellenistic, and Roman antiquities on their soil, an attitude followed later in the nineteenth century by their giving permission for official excavations by Germans and Austrians in Troy and Ephesus in the western part of Asia Minor (Uslu 2017). The classicist trend and, because of it, Philhellenism changed European attitudes: the Parthenon was a foundational part of European civilization and had to be saved! So, is archaeology a national or an 'inter-national' discipline (Mazower 2008, 35), and 'Why have the Parthenon sculptures retained their paradigmatic character, their appeal as the peak of ancient Greek and human achievement in our post-modern era?' (Voutsaki 2017, 1) Can Archaeology lead to nationalism or to supra-nationalism and to supra-regional identities? Apart from these political or ideological questions Archaeology, like History, is a discipline with a specific scientific methodology, and as such warrants our consideration and respect.

To the triple division of archaeology proposed by Bruce Trigger into nationalist, colonialist, and imperialist archaeology (Trigger 1984, 355-370), Yannis Hamilakis (2008, 273-284) has added 'indigenous archaeology', which combines a sentimental attitude on the part of local people towards an antiquity or ancient monument in their environment during the pre-nationalist era and their empirical knowledge of it. It is often maintained that it was the Western Europeans who discovered ancient Greek culture: they made the first excavations, also during the Ottoman era, and it was thanks to them that the classical age of Ancient Greece became known to the Greek people, who, according to many Europeans, at the time were ignorant, illiterate, etc. However, while the impact of the classicist movement on the formation of modern Greek national identity is partly true, it is also very simplistic, as it fails to take into account the vast body of historical material concerning how aware Greek intellectuals during the Byzantine and post-Byzantine eras were of Antiquity. In 
Greek schools, both in the Ottoman Empire and in the Greek diaspora, pupils were

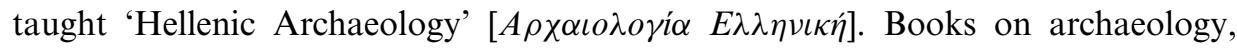
which is to say 'ancient history', or compilations about Hellenic antiquities [ $\alpha \rho \chi \alpha i o ́ \tau \eta \tau \varepsilon \varsigma \varepsilon \lambda \lambda \eta \nu 1 \kappa \varepsilon ́ \varsigma]$ had been published since the eighteenth and early nineteenth centuries (Katsiardi-Hering et al. 2018, 302; Ladas and Chatzidimos 1973; Ilioú 1997). This was not archaeology as a scientific discipline, but it addressed the need for antiquity, and Greek ancient history in particular, to be taught.

Under the influence of Benedict Anderson's Imagined communities and of the linguistic turn, postmodernist approaches led to a more or less constructivist theory of the establishment of Greek (among others) national identity. This is really a huge discussion and this article is not the place to discuss it at length - I have done so elsewhere (Katsiardi-Hering 2019). What I would simply like to note is that most of the authors who take up this constructivist line generally base their views on secondary literature, especially from the end of the eighteenth and early nineteenth centuries. It is here that I locate a weakness in the argument. Because of the scope of this article, I restrict my argumentation to the historical era after the fifteenth century. A great number of Greek intellectuals during the dialogue between the Catholic and Orthodox churches in the fifteenth century (Harris 1995) and after the fall of Constantinople to the Ottomans in 1453 migrated to the West. Of course, many of them were attracted by the intellectual awakening of the Renaissance. The Greeks in the Levant at the time were divided under Ottoman and Venetian rule. Greek intellectuals established printing houses and schools in Venice, Vienna, Budapest, Iasi, etc. and studied and taught at European universities (Staikos and Sklavenitis 2001). Thus the route connecting East and West via education was kept open throughout the period, providing a genuine bridge for dialogue, either real or imaginary (Heppner and Katsiardi-Hering 1998). Taking all this into consideration, we can trace an almost uninterrupted communication with the West and what was thought of as 'Europe' at the time. At the same time, according to the historical sources available since the thirteenth century, there was a belief among Greek scholars that they were descended from the ancient Greeks or had a lot in common with their culture (Katsiardi-Hering et al. 2018). This attitude grew stronger in the Enlightenment era, when the Greek commercial as well as intellectual diaspora constituted a presence in several European cities (Bibliography of the Greek Diaspora 2016). We can identify a real or imaginary dialogue with the Europeans with the desire to belong to the 'wise', 'Christian', 'well-governed' Europe and to work towards this goal (Katsiardi-Hering 2005, 237-252). Europe was the measure of comparison, the lighthouse, the mirror. It is not surprising, then, that through this dialogue and because of changing cultural trends in Europe in the late eighteenth and early nineteenth centuries, an osmosis took place in Europe and among the Greeks in the Levant, which supported the Greeks in their war for independence.

The idea of the 'revival', 'la régénération' (Pouqueville 1824), 'die Wiedergeburt' (Krug 1821), of Greece came as a consequence of this dialogue and was one of the central cultural visions among European classicists. The interest in the Greek War of Independence provoked or strengthened Philhellenism. The founding of cultural 
societies in 1813 in Athens and in 1814 in Vienna under the name ' $\Phi$ ८ $\lambda$ ó $\varepsilon \tau \alpha \iota \rho \varepsilon \alpha^{\prime}$ ' (the Society of the Friends of the Muses) (Tolias 2012, 96-97), whose aim was to provide Hellenic education but with an interest in antiquities, as well as the writings of the great intellectual Adamantios Korais in Paris and of other scholars prove that among Greek communities everywhere there as an interest in the protection of ancient statues and monuments. The revolutionary governments during the Greek Revolution issued a number of laws (Voudouri 2008, 125-139) safeguarding antiquities, arranging for their collection in schools and museums, and prohibiting their sale to foreign travellers.

The Bavarians that formed the first government around the young King Otto (1833-1843) laid the foundations for the protection of antiquities, establishing the first Archaeological Society in Athens (Petrakos 1987). But it would be an exaggeration to credit only them with the establishment of archaeology in Greece. Archaeology, as a genuine discipline concerned with classical and roman antiquity, was taught at the first Greek university established in Athens in 1837 (Karamanolakis 2008, 185-196), and was held in high esteem by every government in Greece, and not only by the Bavarians. Greece was also the first state that ruled that foreign archaeological societies should leave the findings of their excavations in the country itself. Finally, Archaeology has been held in high esteem in Greece until today and very often features in current governmental policy (Association of Greek Archaeologists 2002; Garoufalis and Konstantinidi-Syvridi 2002).

Nationalism, as an ideology that led to the formation of the European nation states in the nineteenth century, relied (amongst other things) on Herderian theory. One of the cornerstones of nationalistic theory was the search for roots in the most ancient past of the civilization and history concerned. The first nation state founded in Southeastern Europe was Modern Greece in the wake of the Greek Revolution. Given that many Bulgarian and Albanian intellectuals studied in Greece and that Greek education was present in their lands, I dare argue that Greece functioned as a 'paradigm' for most of the nationalisms in the region. Archaeology became one of the cornerstones of the formation of a people's national identity, along with religion, language, geography and traditions. It is not oxymoronic that the Bulgarians should have propounded inter alia the Thracian archaeological past and the continuity of Thracian archaeological and historical presence in their capital city, Sofia (Dikov 2016). In Albanian nationalism, and supported by the Roman Catholic Church, the 'Illyrian' past figured centrally. Romanians (Grumeza 2009; Curry 2015), who formed their nation state in the nineteenth century, looked to their Roman past, and above all to Dacian civilization, which they propounded as a 'great Romania' and the territorial basis of their new state. A more recent example is the so-called 'project Skopje 2014' in the FYROM (Wikipedia 2018; Skopje 2018). This constitutes a newly formed nationalism, an apogee of constructivism, an effort to find roots in the ancient past and an effort to dismiss the prevailing/dominant Slavic presence in the country.

Archaeology, traditionally part of the humanities, today leans more and more towards the natural and technical sciences, with electronic space mapping, 
environmental studies, with the study of how flora have evolved down the centuries, and the study of human evolution and movement. Archaeology is now tending towards Biology, Biogenetics, DNA analysis, etc., which are useful for the study of the evolution of mankind, of its diseases, the causes of the demise of huge populations, human movements, etc. But we have to be careful how we use, for instance, DNA analysis and the conclusions that may be drawn from it, given that their non-scientific abuse could well return us to the awful racial nationalisms of the past or to attempts of unhistorical explanations of the past and present.

Archaeological excavations, the study of monuments and the evolution of architectural and material culture can prove, and have proved, that Europe has undergone migrations of many peoples throughout the centuries and such migrations are still continuing. European civilization and European peoples have known continuities, discontinuities, mixtures of populations, and cultural transfers, and continue to do so. The science of history, based on reliable historical sources and their scientific elaboration, can contribute to a better understanding of a common historical past and to respect for the differences between regions and local or ethnic cultures, away from aggressive nationalism and historical distortions, as well as from mythical reductions or reconstructions of the past.

\section{Acknowledgements}

I would like to thank my colleagues Nina Kyparissi-Apostolika, Dimitris Plantzos and Giorgos Vavouranakis for their advice.

\section{References}

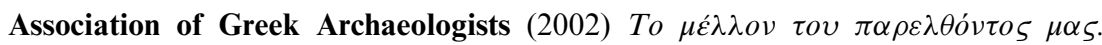

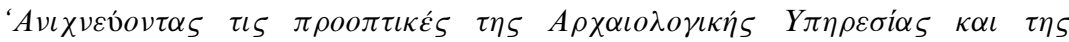

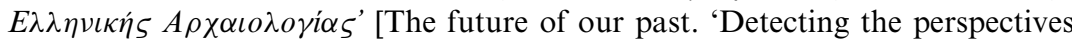
of the Archaeological Office and of the Greek Archaeology'.] Proceedings of the Fourth Congress of the Association of Greek Archaeologists, Athens. 24-26 November 2000. Athens: Association of Greek Archaeologists.

Bibliography of the Greek Diaspora 15th-19th century (2016) University of Athens. Available at http://diaspora.arch.uoa.gr/main/index.php (accessed 12 February 2018).

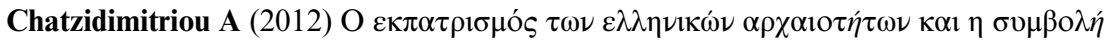

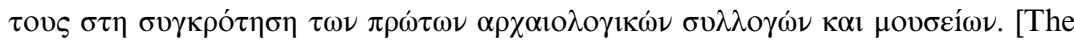
expatriation of the Hellenic antiquities and their contribution to the establishment of the first archaeological collections and museums.] In Matthaiou $\mathrm{S}$ and

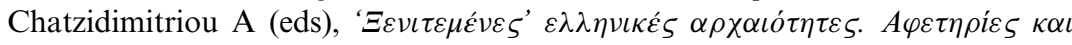
$\delta \iota \alpha \delta \rho \mu \varepsilon^{\prime} \varsigma$ [Migrated' Greek antiquities. Starting points and itineraries]. Athens: National Hellenic Research Foundation, pp. 33-78.

Chatsiaslani K (2016) Morosini in Athens. Available at http://www.eie.gr/ archaeologia/En/chapter_more_8.aspx (accessed 13 February 2018).

Curry A (2015) Gold looted from ancient empire returned to Romania. National Geographic 20 March. Available at http://news.nationalgeographic.com/2015/ 
03/150320-romanian-dacian-sarmizegetusa-gold-looted-recovered/ (accessed 12 February 2018).

Damaskos D and Plantzos D (eds) (2008) A Singular Antiquity. Archaeology and Hellenic Identity in Twentieth-century Greece. Athens: Mouseio Benaki, 3rd Supplement.

Dettmer M, Hawranek D, Kouvakas T and Reiermann C (2013) Akropolis Adieu! Der Spiegel, 21 December 2013. Available at www.spiegel.de/spiegel/print/d124097508.html (accessed 18 February 2018).

Díaz-Andreu M and Champion T (eds) (1996) Nationalism and Archaeology in Europe. London: UCL Press.

Dikov I (2016) Archaeology in Bulgaria. Bulgaria's most famous Thracian treasure the Panagyurishte gold treasure, to 'return home town' after two-year lapse. Available at http://archaeologyinbulgaria.com/2016/06/13/bulgarias-most-famousthracian-treasure-the-panagyurishte-gold-treasure-to-return-to-home-town-aftertwo-year-lapse/ (accessed 12 February 2018).

Eldem E (2011) From blissful indifference to anguished concern: Ottoman perceptions of antiquities, 1799-1869. In Bahrani Z, Çelik Z and Eldem E (eds), Scramble for the Past. A Story of Archaeology in the Ottoman Empire, 1753-1914. Istanbul: SALT, pp. 287-301.

Fatsea I (2017) The reception of J.J. Winckelmann by Greek scholarship during the formative stage of the Modern Greek state (1832-1862). In Voutsaki S and Cartledge P (eds) Ancient Monuments and Modern Identities. A Critical History of Archaeology in 19th and 20th Century Greece. New York: Routledge, p. 62.

Focus (2010) Online Focus Video 20 February 2010. Available at https://www.focus. $\mathrm{de} / \mathrm{magazin} /$ videos/focus-titel-betrueger-in-der-euro-familie_vid_15672.html; '2000 Jahre Niedergang. Von der Wiege Europas zum Hinterhof Europas: Griechenlands Abstieg ist beispiellos. Wie konnte das passieren?' 22 February 2010. Available at https://www.focus.de/finanzen/news/staatsverschuldung/wirtschaft2000-jahre-niedergang_aid_482500.html (accessed 18 February 2018).

Focus (2011) Online Focus Video 18 September 2011. Available at https://www.focus. de/magazin/videos/focus-titel-ist-unser-geld-verloren_vid_27063.html (accessed 18 February 2018).

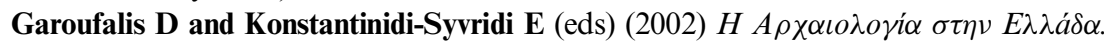

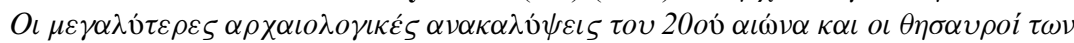

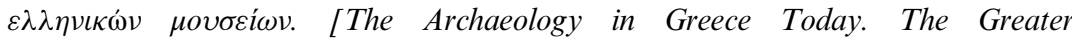
Archaeological Discoveries in the 20th Century and the Treasures of Greek Museums.] Athens: Corpus, vol. 2.

Grumeza I (2009) Dacia, Land of Transylvania, Cornerstone of Ancient Eastern Europe. Lantham: Hamilton Books.

Halbertsma RB (2003) Scholars, Travellers and Trade. The Pioneer Years of the National Museum of Antiquities in Leiden, 1818-1840. London, New York: Routledge, Taylor \& Francis Group.

Hamilakis Y (2008) Decolonizing Greek archaeology: indigenous archaeologies, modernist archaeology and the post-colonial critique. In Damaskos D and Plantzos D (eds), A Singular Antiquity. Archaeology and Hellenic Identity in Twentieth-century Greece. Athens: Mouseio Benaki, 3rd Supplement, pp. 273-284.

Harris J (1995) Greek Emigrés in the West, 1400-1520. Camberley, Surrey: Porphyrogenitus.

Heppner H and Katsiardi-Hering O (eds) (1998) Die Griechen und Europa. Außenund Innensichten im Wandel der Zeit. Wien: Böhlau. 


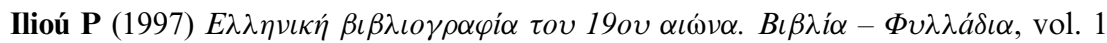
(1801-1818). Athens, No. 1804/3, 1815/21, 1815/90 and many others.

Karamanolakis V (2008) University of Athens and archaeological studies: the contribution of archaeology to the creation of a national past (1911-1932). In Damaskos D and Plantzos D (eds), A Singular Antiquity. Archaeology and Hellenic Identity in Twentieth-century Greece. Athens: Mouseio Benaki, 3rd Supplement, pp. 185-196.

Katsiardi-Hering O (1989) L'idée de la Révolution dans l'horizon politique des Grecs de Hongrie (fin XVIIIe siècle. In La Révolution Française et l' Hellénisme moderne, Actes du IIIe colloque d'histoire, Athènes 14-17 OК $\tau$. 1987. Athènes: Fondation Nationale de la Recherche Scientifique, pp. 87-118.

Katsiardi-Hering O (1999) L'impresa al di sopra di tutto: parametri economici del martirio di Rigas. In Marcheselli-Loukas L (ed.), Rigas Fereos, la Rivoluzione, la Grecia, i Balcani. Atti del Convegno Internazionale 'Rigas Fereos- Bicentenario della morte', Trieste, 4-5 December 1997. Trieste: Lint, pp. 59-81.

Katsiardi-Hering O (2005) Die Europaidee in den Texten des griechischen Unabhängigkeitskrieges (1821-1829). In Clewing K and Schmitt OJ (eds) Südosteuropa: von vormoderner Vielfalt und nationalstaatlicher Vereinheitlichung, Festschrift für Edgar Hösch, Südosteuropäische Arbeiten, vol. 127. München, 2005, pp. 237-252.

Katsiardi-Hering O (2009) Von den Aufständen zu den Revolutionen christilicher Untertanen des osmanischen Reiches in Südosteuropa (ca. 1530-1821). Ein Typologisierungsversuch. Südost-Forschungen 68, 96-137.

Katsiardi-Hering O (2018) La Presenza dei Greci a Trieste (1751-1830). La Comunità e l'attività economica (1751-1830), 2 vols, translated from Greek. Trieste: Lint.

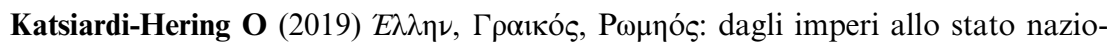
nale. In Re M, Rognoni C and Vuturo P (eds). Ritrovare Bisanzio. Atti delle Giornate di Studio sulla civiltà bizantina in Italia meridionale e nei Balcani dedicate alla memoria di André Guillou (Palermo, 26-26 Maggio 2016). Palermo: Istituto Siciliano di Studi Bizantini e Neoellenici, Quaderni, 20. Byzantino-Sicula VII, 333-358.

Katsiardi-Hering O, Papadia-Lala A, Nikolaou K and Karamanolakis V (eds) (2018) Hellene, Romios, Greek: Collective Identifications and Identities. Athens: Eurasia.

King D (2006) The Elgin Marbles. London: Hutchinson.

Kitromilides PM (2013) Enlightenment and Revolution. The Making of Modern Greece. Cambridge MA, London: Harvard University Press.

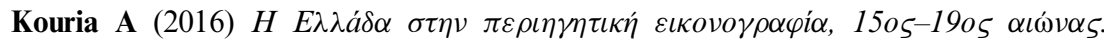

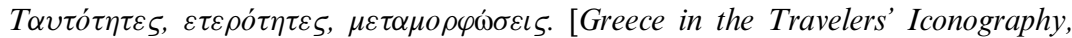
15th-19th Century. Identities, Otherness, Transformations.] Athens: Foundation Panagiotis and Efi Micheli.

Krug W (1821) Griechenlands Wiedergeburt. Ein Programm zum Auferstehungsfeste. Available at http://reader.digitale-sammlungen.de/de/fs1/object/display/bsb10718410_ 00011.html

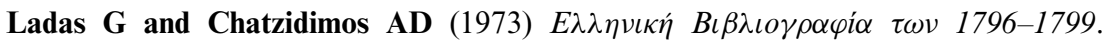
Athens, No. 1796/4.

Leppmann W (1986) Winckelmann: ein Leben für Apoll; das rätselhafte, dramatische Lebensschicksal des Mannes, der als 'Vater der Archäologie' und Begründer der deutschen Klassik Epoche machte. Frankfurt am Main: Fischer-TaschenbuchVerlag. 


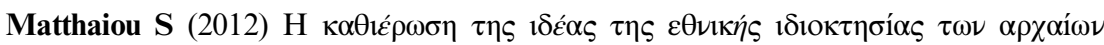
$\mu \nu \eta \mu \varepsilon i \omega \nu$ [The introduction of the idea of the national ownership of the ancient

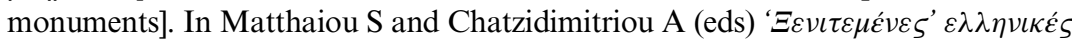

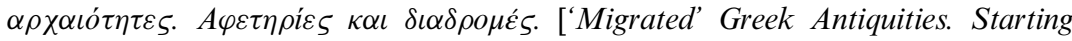
Points and Itineraries.] Athens: National Hellenic Research Foundation, pp. 15-32.

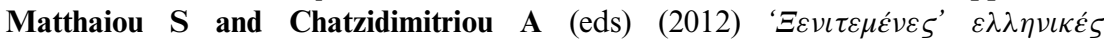

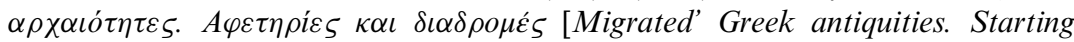
points and itineraries]. Athens: National Hellenic Research Foundation.

Mazower M (2008) Archaeology, nationalism and the land in modern Greece. In Damaskos D and Plantzos D (eds) A Singular Antiquity. Archaeology and Hellenic Identity in Twentieth-century Greece. Athens: Mouseio Benaki, 3rd Supplement, p. 35.

Museo d'Antichità J.J. Winckelmann (2015) Trieste. Available at http:// museoantichitawinckelmann.it (accessed 12 February 2020).

Nebojsa Tower (2014) The website of the historical exhibition on Rigas, organized through Greek-Serbian cooperation. Available at https://kulanebojsa.rs/?lang=en (accessed 12 February 2020).

Papadia-Lala A (2015) Antiquity and the cultural environment in the GreekVenetian East (15th-18th centuries). Thesaurismata 45, 361-370.

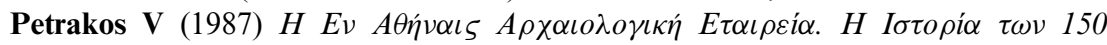

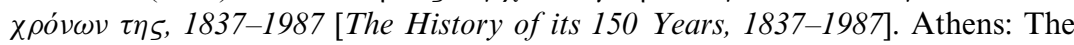
Archaeological Society of Athens.

Pouqueville FCHL (1824) Histoire de la régénération de la Grèce comprenant des événements depuis 1740 jusqu'en 1824. Paris: Firmin Didot Père et fils.

Quitrieste (2012) Arte Storia su Trieste e dintorni. Locanda Grande di Trieste. Available at http://quitrieste.it/tag/locanda-grande-di-trieste/ (accessed 12 December 2017).

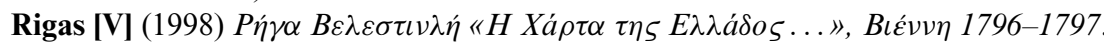
Athens: Scientific Society of Studies Pheres - Velestino - Rhigas.

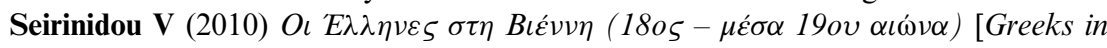
Vienna (18th - middle 19th Century]. Athens: Herodotos.

'Skopje 2014 Uncovered' (2018). Available at http://skopje2014.prizma.birn.eu.com/en (accessed 13 February 2018).

Smith L (2004) Archaeological Theory and the Politics of Cultural Heritage. London, New York: Routledge/Taylor \& Francis.

Staikos K and Sklaventitis TE (eds) (2001) The Publishing Centres of the Greeks from the Renaissance to the Neohellenic Enlightenment: Catalogue of Exhibition. Athens: National Book Centre of Greece.

Stouraiti A (2001) Memorie di un ritorno. La Guerra di Morea (1684-1699) nei manoscritti della Querini Stampalia. Venezia: Fondazione Scientifica Querini Stampalia.

Tolias G (2005) Antiquarianism, patriotism and empire: transfers of the cartography of the travels of Anacharsis the Younger in Greece (1788-1811). The Historical Review/La Revue Historique 2, 67-91.

Tolias G (2008) National heritage and Greek revival: Ioannis Gennadios on the expatriated antiquities. In Damaskos D and Plantzos D (eds) $A$ Singular Antiquity. Archaeology and Hellenic Identity in Twentieth-century Greece. Athens: Mouseio Benaki, 3rd Supplement, pp. 55-56.

Tolias G (2011) An inconsiderate 'love of the arts': the spoils of Greek antiquities 1780-1820. In Bahrani Z, Çelik Z and Eldem E (eds), Scramble for the Past. A 
Story of Archaeology in the Ottoman Empire, 1753-1914. Istanbul: SALT, pp. 71-94.

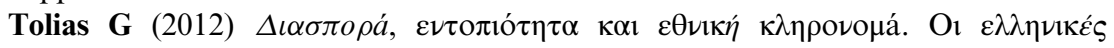

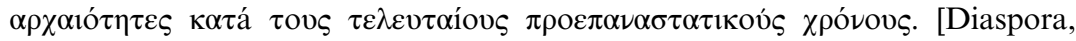
locality and national heritage. The Greek antiquities during the last prerevolution-

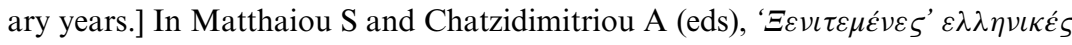

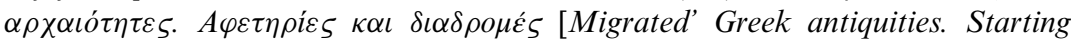
points and itineraries]. Athens: National Hellenic Research Foundation.

Trigger BG (1984) Alternative archaeologies: nationalist, colonialist, imperialist. Man, New Series 19(3), 355-370.

Uslu G (2017) Homer, Troy and the Turks. Heritage and Identity in the Late Ottoman Empire, 1870-1915. Amsterdam: Amsterdam University Press.

Voudouri D (2008) Greek legislation concerning the international movement of antiquities and its ideological and political dimensions. In Damaskos D and Plantzos D (eds) A Singular Antiquity. Archaeology and Hellenic Identity in Twentieth-century Greece. Athens: Mouseio Benaki, 3rd Supplement, pp. 125-139.

Voudouri D (2015) Le droit hellénique du patrimoine archéologique. In Négri V (ed.), Le patrimoine archéologique et son droit. Questions juridiques, éthniques et culturelles. Actes du colloque international, 9 et 10 octobre 2012, Musée du quai Branly (Paris). Bruxelles: Bruylant, pp. 293-306.

Voutsaki S (2017) Introduction. Ancient monuments and modern identities. In Voutsaki S and Cartledge P (eds), Ancient Monuments and Modern Identities. A Critical History of Archaeology in 19th and 20th Century Greece. New York: Routledge, p. 1.

Voutsaki S and Cartledge P (eds) (2017) Ancient Monuments and Modern Identities. A Critical History of Archaeology in 19th and 20th Century Greece. New York: Routledge.

Wikipedia (2017) 'Elgin Marbles'. Available at https://en.wikipedia.org/wiki/Elgin

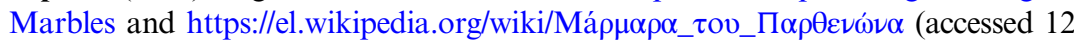
February 2020).

Wikipedia (2018) 'Skopje 2014'. Available at https://en.wikipedia.org/wiki/ Skopje_2014 (accessed 13 February 2018).

\section{About the Author}

Olga Katsiardi-Hering is Professor of Modern Greek History (1453-1828) at the National and Kapodistrian University of Athens. Her recent publications include: 'L'area balcanica nei secoli XVI-XVIII sotto l'Impero Ottomano', in Europa e il Mediterraneo, Vol. XII. Popoli, stati, equilibri del potere, a cura di Roberto Bizzocchi, Salerno Editrice, Roma 2013, 613-648; 'Commerce and merchants in Southeastern Europe, 17-18th centuries: 'Micro-districts' and Regions', Études Balkaniques LI:1 (Sofia, 2015), 19-35; Victor N. Zakharov, Gelina Harlaftis, Olga Katsiardi-Hering (eds), Merchant Colonies in the Early Modern Period, London, Vermont: Pickering \& Chatto, 2012, 245pp; Olga Katsiardi-Hering and Maria A. Stassinopoulou (eds), Across the Danube: Southeastern Europeans and their Travelling Identities (17th-19th C.). Leiden, Brill, 2017. 